УАК 616.314-089

(C). К. Аобровольська, В. М. Гелей, Н. І. Гелей

АВНЗ «Ужгородський національний університет»

\title{
Стан біоенозу клінічних зубоясенних кишень хворих на генералізований пародонтит
}

Резюме. Вивчено кількісний та якісний склад мікроорганізмів зубоясенних кишень у хворих на генералізований пародонтит різного ступеня тяжкості. Запропоновано методику збільшення висівання аеробів зубоясенних кишень. 3 метою нормалізації біоценозу запропоновано нозодовий антигомотоксичний препарат та імуномодулятори.

Ключові слова: генералізований пародонтит, біоценоз, зубоясенні кишені, антигомотоксичний препарат, імуномодулятори.

\section{М. К. Аобровольская, В. М. Гелей, Н. И. Гелей \\ ГВУЗ «Ужгородский национальный университет» \\ Состояние биоценоза клинических зубодесневых карманов больных генерализованным пародонтитом}

Резюме. Изучены количественный и качественный состав микроорганизмов зубодесневых карманов у больных генерализованным пародонтитом различной степени тяжести. Предложенная методика увеличения высеваемости аэробов. С целью нормализации биоценоза рекомендован нозодный антигомотоксический препарат и иммуномодуляторы.

Ключевые слова: генерализованный пародонтит, биоценоз, зубодесневые карманы, антигомотоксический препарат, иммуномодуляторы.

\section{K. Dobrovolska, V. M. Heley, N. I. Heley \\ SHEI «Uzhhorod National University» \\ Clinical status ecological communiy dentogingival pocket patients with generalized periodontitis}

Summary. The quantitative and qualitative composition of microorganisms in periodontal pockets of patients with generalized periodontitis of varying severity was stadied. The technique of increasing aerobic detection of periodontal pockets was proposed. In order to normalize the biological community nosodes antihomotoxic offered drugs and immunomodulators was proposed.

Key words: generalized periodontitis, biocenosis, periodontal pockets, Antihomotoxic drug, immunomodulators. 
Вступ. Бактеріальний склад вмісту зубоясенних кишень у хворих із запально-дистрофічними процесами в тканинах пародонта був предметом дослідження багатьох авторів [1 -4]. Одні з них досліджували окремі види бактерій, інші - їх чутливість до антибіотиків $[2,3]$.

Не всі мікроорганізми було вивчено з однаковою ретельністю. У літературі зустрічаються окремі роботи, присвячені гемофілам, мікоплазмам. У більшості робіт приведені результати досліджень, присвячені властивостям окремих видів мікроорганізмів: стафрілококам, гемолітичним і зеленячим стрептококам, простішим, їх чутливості до антибіотиків $[1,3]$.

Тільки окремі роботи присвячені гемофілам та мікоплазмам.

Не Аивлячись на ретельність планування досліджень, автори отримували суперечливі дані $[3,4]$. Так, відсоток виділених стрептококів складає від 55,3 до 90,3 \%, стафілококів - від 20,8 до 90,3 \%. Мікробний пейзаж зубоясенних кишень не розглядається в його цілості та взаємозв' язку залежно від тяжкості захворювання.

Тому вивчення мікрофлори зубоясенних кишень в асоціаціях залежно від тяжкості захворювання, розробка методики її накопичення в матеріалі вкрай важливо для з' ясування їі культуральних властивостей і пошуку ефективних антимікробних засобів.

Метою роботи стало вивчення складу аеробної мікрофлори зубоясенних клінічних кишень у нормі й при генералізованому пародонтиті залежно від ступеня тяжкості захворювання, вдосконалення методів виділення аеробної мікрофлори в лабораторних умовах.

Матеріали і методи. У 36 пацієнтів (по 18 чоловіків і жінок $20-65$ років) з генералізованою формою пародонтиту проведено 45 мікробіологічних досліджень вмісту зубоясенних кишень.

Усіх хворих поділили на 4 групи: з початковим ступенем пародонтиту -8 чоловік, розвинутим I ступенем захворювання - 7 чоловік, II-III ступенями - 16 чоловік. Контрольну групу склали 5 пацієнтів з клінічно здоровим пародонтом.

Забір матеріалу для мікробіологічного обстеження проводили за допомогою кореневої голки із стерильною турундою, яку в подальшому занурювали у пробірку з м' ясо-пептонним бульйоном із наступним пересівом (не пізніше ніж через 3 год 3 моменту взяття матеріалу) на чашки Петрі з відповідними селек- тивними середовищами. Посіви проводили до і після підрощування культури в термостаті при $37^{\circ} \mathrm{C}$ упродовж 24 год.

Використовували наступні середовища: жовтково-сольове 5 і 10 \% для виділення мікроорганізмів роду Staphylococcus; середовище Гарро - селективне для стрептококів; кров'яний агар із ристоміцином для виділення нейсерій, гліцериновий агар для гемофілів; середовище Сабуро - дріжджів і грибів; середовище Ендо - для виділення представників сімейства кишкових бактерій.

Після зняття зубних відкладень до протоколу лікування, що передбачає застосування антимікробних, протизапальних препаратів, вітамінних комплексів, ми включали підшкірні ін'єкції нозодного імуномоделюючого препарату ехінацеї композитуму, для нормалізації балансу мікрофлори ротової порожнини розсмоктування таблеток «Біогая» та прийом капсул «Аактіалє» 1 раз на добу після їжі.

Результати досліджень та їх обговорення. Мікробіологічне дослідження показало, що при прямому посіві ріст мікрофлори спостерігали лише у 15 випадках із 45. Разом з тим, після підрощування в термостаті при $37^{\circ} \mathrm{C}$ протягом 24 год число позитивних результатів збільшувалось до 44.

Після підрощування спектр мікроорганізмів значно розширювався. Так, ентеробактерії, протеї, коринебактерії, дріжджоподібні гриби, спороутворювальні палички були виділені тільки після підрощування. Таке ж виділення після підрощування було характерно для гемофрілів і стафілококів. Нейсерії і стрептококи частіше виділялися після підрощування, порівняно з прямими посівами, у $2-8$ разів.

Частота виділення різних мікроорганізмів, залежно від ступеня захворювання, характеризувалась переважним перебуванням стрептококів і нейсерій в зубоясенних кишенях як здорових, так і хворих на пародонтит.

У 40 \% випадків здорових пацієнтів були виділені епідермальні стафілококи і грибки роду Candida. Гемофріли, протеї, коринебакатерії виявлялися у 20 \% випадків. Вже при початковій стадії захворювання це співвідношення порушувалось за рахунок появи грамнегативних спороутворювальних паличок, ентеробактерій і золотистого стафрілокока, зменшення числа коринебактерій, епідермальних стафілококів і нейсерій, значного збільшення стрептококів.

При І ступені захворювання зберігалась тенденція до переважної присутності стрепто- 
коків. Кількість же нейсерій, порівняно з початковим ступенем захворювання, збільшувалася із 25 до 71,2 \%. Та ж тенденція до підвищення була характерною Аля спороутворювальних паличок і стафілококів. Натомість кількість коринебактерій зменшувалась.

При II - III ступенях захворювання спостерігали різке зниження реактивності організму хворого (за даними В. С. Іванова та співавт., 1988), при цих ступенях пародонтиту показники неспецифічного імунітету зменшуються у 8 разів нижче норми, встановлюється нове співвідношення між мікроорганізмами зубоясенної кишені. Це супроводжувалось зменшенням кількості стрептококів (до 55,5 \% проти $100 \%)$ значним зростанням числа нейсерій (74,9 \% проти 25 \% у початковій формі захворювання). Стафілококи і гемофіли були наявними в рівних кількостях в той час, як коринебактерії і грамнегативні спороутворювальні палички залишались у незначній кількості.

При аналізі видового складу мікроорганізмів можна відмітити, що із стрептококів переважали зеленящі, а зі стафілококів - епідермальні. Золотистий стафілокок було виявлено лише у 15 \% випадків при початковій формі захворювання.

Iз нейсерій переважали N. perflava та N. flava. У здорових пацієнтів N. perflava виявляли у незначній кількості, а N. flava зовсім не спостерігали.

При початкових ознаках захворювання i І ступені в значній кількості з'являлись N. subflava i N. flava. Нове співвідношення між видами нейсерій встановлювали при II - III ступенях захворювання, коли були присутніми усі перераховані види, за винятком N. flava, але $з$ перевагою N. perflavaта та N. mucosa.

Із гемофілів у нашому дослідженні зустрічався H. aphrophylus, який проявляв тенденцію до зменшення у пацієнтів із І ступенем захворювання, залишаючись приблизно на одному рівні у хворих з початковим II - III ступенями пародонтиту, а також у здорових.

\section{Список літератури}

1. Иванов В. С. Заболевания пародонта / В. С. Иванов. - М. : Медицина, 1998. - 280 с.

2. Yibbons R. Y. Microbiology of periodontal. Textbook of Oral Biology / R. Y. Yibbons, Y. Van Houte, I. H. Show // Philadelphia. - W. B. Sanders Co, 1977.

3. Page R. S. Pathogenesis of inflammatory periodontal disease. A summary of current work / R. S. Page,
При підрахунку кількісного видового складу мікроорганізмів, що одночасно були присутніми в зубоясенних кишенях, найчастіше виявляли $1-2$, рідше $3-4$ види бактерій. Поліфрлора і більш масивний ріст були характерними для II - III ступенів захворювання.

Кількість колоній на чашці коливались від поодиноких до суцільного росту. Колонії в кількості до 50 були характерними для нейсерій при всіх ступенях захворювання і стафілококах при II - III ступенях.

Суцільний ріст колоній спостерігали у стрептококах, особливо при II - III ступенях пародонтиту.

Висновки. 1. Мікробіологічне обстеження показало, що при прямому посіві ріст мікрофлори спостерігається лише у незначній кількості (15 випадків із 45).

2. Підрощування мікрофдори в термостаті при $37{ }^{\circ} \mathrm{C}$ упродовж 24 год сприяє підвищенню висівання мікробів до 44.

3. Аля кожного ступеня захворювання і здорових осіб характерне специфічне співвідношення різних видів мікроорганізмів.

4. Кожний із видів мікроорганізмів має тенденцію до накопичення залежно від ступеня тяжкості захворювання на генералізований пародонтит.

5. Аля генералізованого пародонтиту усіх ступенів тяжкості характерний дисбактеріоз зубоясенних кишень.

6. Аля успішного лікування дистрофічнозапальних захворювань пародонта зусилля лікаря повинні бути направлені на:

а) підвищення неспецифічного імунітету;

б) ліквідацію дисбактеріозу вмісту клінічних зубоясенних кишень.

Перспективним є призначення лікувального комплексу, дія якого направлена на нормалізацію біоценозу ротової порожнини та імуномодуляцію реактивності організму: ін'єкції ехінацеї композитум, жувальних таблеток «Біогая» та капсул «Лактіалє».

Подальші дослідження будуть направлені на вивчення цієї проблеми.

H. E. Shroeder // Lab. Invest. - 1976. - Vol. 33. P. 235- 245 .

4. Терапевтична стоматологія у чотирьох томах. Захворювання пародонта / [М. Ф. Аанилевський, А. В. Борисенко, А. М. Політун та ін.]. - К. : Медицина, 2008. - T. 3. -614 c.

Отримано 05.05.14 